\title{
AZ „UTOLSÓ CSOKI" MÁR TÚL KÉSŐ - SZÜLŐK ÉS GYERMEKEK ELTÉRŐ VÉLEMÉNYE A GYERMEKEK TÁPLÁLKOZÁSI SZOKÁSAIT ILLETŐEN
}

\section{THE 'LAST PIECE OF CHOCOLATE' IS TOO LATE - INVESTIGATING DIFFERENCES IN PARENTS' AND CHILDREN'S OPINIONS OF THE CHILD'S EATING BEHAVIOUR}

\begin{abstract}
A gyerekek étkezésére számos tényező van hatással, melyek közül a szülők szerepe kiemelkedő. A szerzők kutatásuk során a gyerekek evési magatartását vizsgálták egy sajátos megközelítésből. Kutatásuk fő kérdése az volt, hogy a szülők menynyiben másként ítélik meg gyermekük evési magatartását, mint maga gyerek? Mindezt a gyerekek BMI-kategóriái szerint szegmentált módon kutatták. Vizsgálódásuk során a DEBQ (Dutch Eating Behavior Questionnaire) gyerekekre adaptált változatát használták fel. A mintát 433 általános iskolás korú gyerek (3-6. osztály) és szüleik alkották. A cél egyrészt az volt, hogy a gyerekekre adaptált skála használhatóságát megerősítsék, másfelől pedig az, hogy rávilágítsanak arra, hogy a szülők másként ítélik meg a gyermekük táplálkozási sajátosságait, mint maga a gyermek. Eredményeik azt mutatják, hogy a szülők felülértékelik gyermekeik önmegtartóztató képességét a táplálkozás terén, így feltételezhető, hogy kevésbé veszélyesnek érzékelik az elhízás kockázatát gyermekük vonatkozásában, csak akkor látják be gyermekeik önkontrollproblémáit, ha a gyerekek már elhíztak. Másrészt azon szülők, akik tisztában vannak gyermekük gyenge önkontrolljával, megelőzhetik a gyerekek elhízását.
\end{abstract}

Kulcsszavak: evési magatartás, elhízás, DEBQ, faktoranalízis

Children's eating habits are affected by a number of factors, and the role of parents is paramount. This research looks at children's eating behaviour from a specific viewpoint to determine whether the child's eating behaviour is judged differently by parents and the children themselves. The examination was segmented according to the children's BMI category. During this investigation, the authors used the Dutch Eating Behaviour Questionnaire, adapted for children. Their sample comprised 433 primary school-aged children (grades 3-6) and their parents. The authors' aims were to strengthen the usability of the scale adapted to children and to highlight that parents' and children's views of the child's nutritional characteristics are different. The results of the research show that parents overestimate their children's self-restraint in nutrition, so they can assume that they perceive a lower risk of obesity for their child: they see their children's self-control problems only if they are already obese. On the other hand, parents who are aware of their child's poor self-control can prevent them from becoming obese.

Keywords: eating behaviour, obesity, Dutch Eating Behaviour Questionnaire (DEBQ), factor analysis

\section{Finanszírozás/Funding:}

A kutatás az EFOP-3.6.1-16-2016-00008 „Intelligens élettudományi technológiák, módszertanok, alkalmazások fejlesztése és innovatív folyamatok, szolgáltatások kialakítása a szegedi tudásbázisra építve" című pályázat finanszírozásával valósult meg.

The research was funded by the EFOP-3.6.1-16-2016-00008 project "Development of intelligent life science technologies, methodologies, applications and development of innovative processes and services based on the knowledge base of Szeged".

\section{Szerzők/Authors:}

Pető Dalma, PhD-hallgató, SZTE, (peto.dalma@eco.u-szeged.hu)

Dr. Buzás Norbert, tanszékvezető, egyetemi docens, SZTE, (buzas.norbert@med.u-szeged.hu)

A cikk beérkezett: 2020. 08. 06-án, javítva: 2021. 01. 12-én, elfogadva: 2021. 01. 15-én.

This article was received: 06. 08. 2020, revised: 12. 01. 2021, accepted: 15. 01. 2021. 
A z elhízás egyre súlyosabb probléma mind a társadalom, mind a gazdaság számára. Egyre több felnőtt és gyerek túlsúlyos, és arányuk fokozatosan nő (OECD, 2017a). Összehasonlítva a jelenlegi és két évtizeddel ezelőtti adatokat, kimutatható, hogy a túlsúlyos gyerekek száma megduplázódott, míg az elhízott serdülőkorban lévő fiatalok száma megtriplázódott (Vazquez \& Torres, 2012). Az Európai Unió országai között hazánk az első helyet foglalja el a felnőtt lakosságra vetített obezitási arányt vizsgálva (OECD, 2017b). Ez köszönhető a kevés mozgásnak és a magyar konyha sajátosságainak (sok zsír és szénhidrát hasnálata). Az egészséges életmód alapját képző zöldség- és gyümölcsfogyasztás is igen alacsony Magyarországon (Pfau, Müller, Bács \& Bácsné Bába, 2018).

Az elhízás miatti betegségek kezelése az egészségügyi kiadások 5-7\%-át teszik ki, de ehhez még az indirekt költségek is társulnak, mint például a kiesett munka, vagy az egészségügyi rendszeren kívüli kiadások (Finkelstein, Ruhm \& Kosa, 2005). A hazai egészségügyi kiadásokra fordított adatokat megvizsgálva láthatjuk, hogy itthon is egyre több pénzt költenek el a háztartások erre a célra, ezen belül is főként gyógyszerekre, gyógyászati segédeszközökre és egyéb gyógyászati célú javakra (KSH, 2017). A lakosság (saját bevallása alapján) 52\%-a szenved valamilyen krónikus betegségben (KSH, 2015). Egy 2010ben végzett kutatás szerint a magyar lakosság számára az egészség a legfontosabb érték, azonban a megvalósítás során már hátrébb kerül a fontossági sorrendben, hiszen ebben az esetben csak a 14. helyre került (Hofmeister-Tóth, 2016). Hazánkban inkább a magasabb végzettséggel és jövedelemmel rendelkezőkre, a nagyvárosban élőkre és a nőkre jellemző az egészségtudatosság. Azonban ezek a különbségek egyre kisebbek, minél fiatalabb az illető (Malota, Gyulavári \& Bogáromi, 2019).

Az ember egészségi állapotát befolyásoló tényezőket két részre oszthatjuk. A nem befolyásolható kockázati tényezők a velünk született genetikai adottságok, az évek során szerzett tulajdonságok, a nem és a kor. Az általunk is befolyásolható tényező pedig az életmód. Az egészségi állapotot legnagyobb arányban az életmód ( 40\%) határozza meg és csak ezt követik a genetikai tényezők ( $\sim 30 \%)$, a környezeti hatások ( $20 \%$ ) és az egészségügyi ellátás ( 10\%) (Lalonde, 2008). Az életmódbeli tényezők közül a táplálkozás meghatározó az egészségünk szempontjából. Már gyermekkorban kialakulnak étkezési szokásaink, amik befolyásolják későbbi egészségi állapotunkat. A helytelen táplálkozás kihathat egész életünkre, akár meg is rövidítheti azt. Éppen ezért már a gyermekek fiatal korától kezdve figyelmet kell fordítani a megfelelö táplálkozási szokások kialakítására (Huszka \& Dernóczy-Polyák, 2015).

$\mathrm{Az}$ étkezés jelentős részben fogyasztási döntéseinkre vezethető vissza. Az egészségtudatos táplálkozás tulajdonképpen megfelelő ételek választását jelenti, így a fogyasztói magatartás szempontjából releváns vizsgálati terület. Az egészségtudatosan táplálkozó fogyasztó kiemelt figyelmet fordít a zöldségek és gyümölcsök fogyasztására, és étrendjében követi az egészséges étkezési arányokra vonatkozó ajánlásokat. Azonban sajnos minden korcsoport táplálkozása eltér az ajánlottól: kevés zöldséget és gyümölcsöt, de sok, energiában gazdag, rosszabb minőségü ételt fogyasztanak (Black, D’Onise, McDermott, Vally \& O’Dea, 2017). Az egészségestől eltérő evési magatartás gyakran a tájékozottság hiányából fakad, hiszen sokak számára az egészséges életmód egyet jelent a fogyókúrával, valamint úgy gondolják, hogy a cukor teljes kiiktatása az étrendből egészséges (Gál, Soós \& Szakály, 2017).

$\mathrm{Az}$ evéshez kapcsolódó fogyasztói döntéseknél különös figyelmet kell fordítani a gyerekek étkezésének tanulmányozására, mivel a korai életkorban rosszul táplált gyerekek a későbbiekben is hajlamosabbak lesznek betegségekre. Különösen veszélyeztetettek az alacsony jövedelmi rétegből jövő fiatalok, akik alacsony tápanyagtartalommal rendelkező ételekkel táplálkoznak. A szülők rákényszerülnek, hogy olcsó és gyorsan elkészíthető ételeket tegyenek az asztalra, amik sokszor magas kalória- és zsírtartalmúak. A tápanyagszegény gyorsételek térnyerése hozzájárul a manapság egyre növekvő, már gyerekkorban kezdődő elhízáshoz, melynek kezelése egyre nagyobb kihívás világszerte (Khatoon, Ahmed \& Zubair, 2017; Vazquez \& Torres-Iglesias, 2012). Számos krónikus betegség (mint a szív- és érrendszeri betegségek, diabétesz, elhízás) első jelei már gyermekkorban kimutathatók (Black et al., 2017). Ezen kívül pszichológiai betegségek, mint depresszió is társulnak az elhízáshoz, ami még roszszabb életminőséget jelent az illető számára (Vazquez \& Torres-Iglesias, 2012).

Ezek alapján elmondható, hogy rendkívül fontos foglalkoznunk a táplálkozással. Különösen igaz ez a gyerekek szempontjából, hiszen ők a jövő fogyasztói és munkavállalói, ezért egészségi állapotunk kiemelt jelentőséggel bír. A fiatalok táplálkozására számos tényező lehet befolyással, az egyik ilyen a szülők hatása. Jelen kutatás nem a szülő-gyerek kapcsolat pszichológiáját kívánja feltárni, hanem egy sajátos területen lévő eltérésekre kívánunk rámutatni

Kutatásunk során a gyerekek evési magatartását vizsgáltuk, egy újszerű megközelítésből. Kutatási kérdésünk az volt, hogy vajon a szülők gyermekükkel azonos módon ítélik-e meg gyermekeik táplálkozási sajátosságait - vagy másként fogalmazva: képesek-e beazonosítani azokat a táplálkozási sajátosságaikat gyerekeiknél, melyeket azok magukról vallanak. Ezeket a különbségeket a BMI szegmensekén elkülönítve is megvizsgáltuk. A vizsgálathoz kérdőíves kutatást végeztünk általános iskolás korú gyerekek és szüleik körében, melynek eredményeit az alábbiakban ismertetjük.

\section{Elméleti háttér}

A szülői befolyás meghatározó a gyerekek szempontjából, már egészen csecsemőkorban befolyásolják a későbbi étkezési magatartást. Ez a befolyás pedig koránt sem egyértelmü. Egyfelöl erős összefüggés figyelhető meg a szülök és gyermekeik táplálkozási attitüdjei között, hiszen azon szülők gyermekei, akik figyelnek az egészséges táplálkozásra maguk is egészségtudatosabbak, jobban érdeklődnek a téma iránt (Scaglioni, Arrizza, Vecchi \& Tedeschi, 
2011), míg a túlsúlyos anyák gyermekei nagyobb esélylyel válnak maguk is túlsúlyossá (Gibson et al. , 2007). A gyerekek annál kiegyensúlyozottabban táplálkoznak, minél több beleszólása van a szülőknek étkezésükre (Böröndi-Fülöp \& Szakály, 2010). Másfelől azonban meglepö, hogy minél inkább tiltja és korlátozza a szülő a kisgyermek étkezéssel kapcsolatos önálló döntéseit (azaz például tiltja az édességeket), annál nagyobb eséllyel kezd a gyerek egészségtelenül táplálkozni a későbbiekben. Amint saját döntést hozhat az étkezéséről, az egészségtelenebb, eddig tiltott alternatívát fogja választani akkor is, ha egyébként nem éhes (European Food Council, 2012).

\section{A szülők szerepe a gyermekek étkezésében}

Kutatásunk szempontjából különösen fontos azt vizsgálni, hogy a szülők miként ítélik meg gyermekük étkezési magatartását és súlyát, ez a megítélés ugyanis hatással lesz a szülők erre vonatkozó viselkedésére. Egy kutatás szerint (Hong, Peltzer \& Jalayondeja, 2017) a vizsgált szülők 48,5\%-a alulbecsülte gyermeke súlyát, ami ahhoz vezethet, hogy a valósnál pozitívabban ítéli meg étkezési magatartását. Azon túlsúlyos és elhízott gyerekek szülei, akik rosszul ítélték meg gyermekük súlyát, alulbecsülték annak evési mennyiségét is, valamint sokkal egészségesebbnek ítélték táplálkozásukat a valóstól. Ezzel szemben azon szülők, akik tisztában voltak gyermekük túlsúlyával, sokkal reálisabban ítélték meg gyermekük táplálkozását és tisztában voltak az elhízás lehetséges következményeivel is (Hong et al., 2017). Ennek ellentéte, amikor a szülők a normál súlyú gyermeket alultápláltnak észlelik és túletetik, ezzel elhízásba hajszolják (Jeffery, Voss, Metcalf, Alba \& Wilkin, 2005; Pocock, Trivedi, Wills, Bunn \& Magnusson, 2010). Egy görög tanulmány $(n=1759)$ szerint az anyák 83\%-a egészségesebbnek gondolta gyermeke táplálkozását a valósnál (Kourlaba, Kondaki, Grammatikaki, Roma-Giannikou \& Manios, 2009). Egy kanadai tanulmány $(\mathrm{n}=1940)$ szintén azt találta, hogy a szülők 83\%-a érzi úgy, hogy gyermeke egészségesen táplálkozik, ebben az esetben viszont nem vizsgálták a valós táplálkozást. A kanadai nemzeti felmérések alapján az egészségtelen táplálkozás széles körben elterjedt, így arra következtethetünk, hogy ebben az esetben is felülértékelték a szülők gyermekeik táplálkozását (Adamo et al., 2010). Más eredményre jutottak Scott-Andrews és szerzőtársai (2020), akik kutatásuk során a CEBQ (Child Eating Behavior Questionnaire) kérdöívet használva azt találták, hogy a szülők megfelelően észlelték gyermekeik étkezési magatartását, ami a gyermekek BMI és testzsír százalékával összefüggésben volt. Ennek oka az lehet, hogy a kérdőívben az egyes étkezési magatartástípusokat pontosan meghatározták, így a szülők is pontosabban tudták beazonosítani, hogy mi jellemző gyermekeikre (Scott-Andrews, Wengrovius \& Robinson, 2020).

A szülők szerepének fontosságához nem férhet kétség, azonban annak hitelességét illetően már támadhatnak kételyek. Találhatunk bizonyos különbségeket aszerint, hogy a gyermekeket vagy a szüleiket kérdezzük arról, hogy kik és miként befolyásolják a gyermekek étkezési magatartását. Kiss és Szakály (2016) kutatásában úgy találta, hogy a vizsgált középiskolás diákok szerint az anyák szerepe sokkal erősebb, bennük látják inkább az egészséges életmódot támogató személyt, míg az apa szerepe ennél sokkal gyengébb, mégis pozitív. Ennek ellenére a fiatalok csupán 1/3-a véli úgy, hogy az egészséges életmóddal és táplálkozással kapcsolatos kérdéseikre megbízható választ kapnak szüleiktől. Számukra a védőnők és orvosok a hiteles információforrások. Ezen kívül az internet lett a harmadik legfontosabb információs csatorna a fiatalok számára (Kiss \& Szakály, 2016). Holczer és Kiss (2019) ezzel szemben azt találta, hogy a szülők szerint nagyon fontos a példamutatás, úgy vélik, hogy az ő felelősségük gyermekük egészséges életmódjának kialakítása. A szülők nem tartják megfelelőnek az iskolai tájékoztatást, inkább a szakorvosok véleményét tartják hitelesnek.

Érdemes említést tennünk a média hatásáról is, hiszen már ebben a korban is könnyen befolyásolhatják az ételválasztási magatartást. A gyerekek egyre több időt töltenek a képernyő előtt, legyen az akár televízió vagy számítógép. Ezzel együtt egyre több reklámmal találkoznak, amik a gyors ételeket népszerüsítik (Vazquez \& Torres-Iglesias, 2012). A hirdetők által használt technikák befolyással bírnak a gyerekek ételekkel kapcsolatos preferenciáira és a gyorsételek fogyasztására buzdítják őket (Boyland \& Whalen, 2015). A gyerekek márkapreferenciái már ilyen fiatal korban kialakulnak, ami befolyással lehet a későbbi életükre is (Kásler, 2017).

A szakirodalomban számos vizsgálatot találunk arra vonatkozóan, hogy a szülők és a gyermekek evési sajátosságai miként függenek össze (Kiss \& Szakály, 2016; Holczer \& Kiss, 2019; Szakály, 2019), azonban arra vonatkozóan hiányosak az ismereteink, hogy adott gyermek és szülöje mennyiben eltérően ítéli meg a gyermek étkezési magatartását. Tanulmányunkban ezt a kevéssé kutatott területet igyekszünk feltárni.

\section{Az evési magatartás vizsgálata}

Az elhízás és a kapcsolódó betegségek kezelésében és megelőzésében az evési magatartás számít a legfontosabb tényezőnek (Danielsen, Svendsen, Mæhlum \& Sundgot-Borgen, 2013). Az evési magatartás vizsgálata előtt érdemes megjegyezni, hogy az egyes élelmiszerek önmagukban nem egészségesek vagy egészségtelenek, illetve nem érdemes hízlaló vagy zsírégető élelmiszerekről beszélni. A hangsúly ugyanis nem magán az élelmiszeren van, hanem az étkezés módján, azaz az evési magatartáson. A súlygyarapodás eredménye egy egyszerü képlet: ha több kalóriát kap a test, mint amennyit eléget, akkor hosszú távon hízni fog (Dovey, 2010). Az evési magatartás vizsgálata magában foglalja az ételek választásával kapcsolatos motivációt, az étkezés gyakorlatát, a diétát, a hozzá kapcsolódó problémákat, mint például az elhízás és az evési zavarok. Célja, hogy segítse a táplálkozással kapcsolatos elhízás és betegségek kezelését és megelőzését (LaCaille, 2013)

A szakirodalomban számtalan különböző evési magatartást (más néven evési stílust) különböztetnek meg, melyek közül kutatásunk szempontjából az alábbi három - talán legszélesebb körben vizsgált - kategória érdekes: 
érzelmi evés, visszafogott evés és a „gátlástalan” evés (disinhibition) (Herman \& Mack, 1975; Herman \& Polivy, 1975; Stunkard \& Messick, 1985; van Strien, Frijters, Bergers \& Defares, 1986; French, Epstein, Jeffery, Blundell \& Wardle, 2012). Az alábbiakban e három étkezési magatartás jellemzőit mutatjuk be. Elöljáróban fontos megjegyezni, hogy ezek a különböző evési magatartások (evési stílusok) sajátos viselkedéseket jelentenek, melyek nem kizárólagosak, azaz egy ember többféle evési magatartást is folytathat.

$\mathrm{Az}$ érzelmi evés a pszichoszomatikus elméletre támaszkodik, mely szerint azok, akik érzelmek (félelem, harag, szorongás) hatására esznek, nem ismerik fel ezt az ingert, ezért túl sok kalóriát visznek be a szervezetükbe (Kaplan \& Kaplan, 1957). Érzelmi evés esetén a személy egy plusz jelentőséget tulajdonít az élelmiszereknek (Dovey, 2010). A túlsúlyos emberek 75\%-a küzd ezzel a problémával. Gyakran magas zsír- és cukortartalmú ételeket választanak, ezért általában nagyobb a kockázata a cukorbetegségnek és a szívbetegségeknek (Frayn \& Knäuper, 2018). Bár az érzelmek hatása alatt való evés elsősorban a negatív érzelmekhez kapcsolódik, egyes esetekben a pozitív érzelmek okozzák (Ganley, 1989).

Visszafogott evési magatartás esetén az egyén tudatosan visszafogja az élelmiszer-fogyasztást a testsúly csökkentése vagy fenntartása érdekében, ami az anyagcsere folyamatok lassulásához és az éhségérzet csökkenéséhez vezet. Ez első ránézésre egy egészségesebb magatartásnak tünhet, azonban előfordul, hogy az önuralom csökkenésével (például az alkohol vagy a negatív érzelmek miatt), a kognitív önuralom is csökken, és az étkezési viselkedés az ellenkező irányba fordul, ami túlzott táplálékbevitelhez vezet. A visszafogott evés eredményeként az egyén elveszítheti az irányítást az éhség érzete és a telítettség érzés felett, ami érzelmek vagy külső hatásra történő evéshez vezet (Herman \& Polivy, 1975).

A gátlástalan evés azt a fajta evési magatartást jelenti, amikor az egyén elveszti az irányítást valamilyen oknál fogva étkezése felett, azaz tudatosan nem kontrollálja táplálékbevitelét és többet eszik, mint amennyit eredetileg szeretett volna. Egy klasszikus példa erre, amikor filmnézés közben sokkal több rágcsálni valót eszünk és rengeteg üdítőt megiszunk. Ez azért van, mert a másik cselekvés (ebben az esetben a filmnézés) elvonja a figyelmet, így nem vesszük észre, hogy mennyit eszünk. A külső hatásra történő evés a gátlás elvesztéséhez kapcsolódó étkezési magatartásnak egy speciális formája. A külső hatásra történő evés során a külső környezet határozza meg az étkezési viselkedést, és az élelmiszerek látványa és illata olyan erős reakciót vált ki melynek a fogyasztó nem tud ellenállni, és korábbi szándéka ellenére többet eszik, mint tervezte (Schachter \& Rodin, 1974). Ezt az elméletet gyakran kapcsolják az elhízáshoz (Herman \& Polivy, 1975).

Az evési magatartással és attitűdökkel számos kutatás foglalkozik, több mérési módszert is kifejlesztettek ennek vizsgálatára. Garner és Garfinkel (1979) Evési attitüdök tesztjével (Eating attitude test - EAT) főként az étkezési zavarok vizsgálhatók. Herman és Polivy (1980) Korlátozás skálájával azt mérhetjük, hogy az egyén mennyire tudatosan korlátozza a táplálékbevitelt, hogy ezzel testsúlyát korlátozza. Ez a kérdöív adta a Háromfaktoros evési magatartás kérdőív (Three Factor Eating Questionnaire - TFEQ) (Stunkard \& Messick, 1985) és a Holland evési magatartás kérdőív (Dutch Eating Behavior Questionnaire - DEBQ) (van Strien et al., 1986) alapját. Mindkettő három evési magatartást vizsgál: a TFEQ a kontrollálatlan evést, a kognitív korlátozást és az érzelmi evést különbözteti meg, a DEBQ pedig a visszafogott evést, az érzelmi evést és a külső hatásokra történő evést.

Jelen kutatás során a Holland evési magatartás kérdőív (DEBQ) egy adaptációját használtuk fel. Ezt a kérdőívet 1986-ban van Strien és társai fejlesztették ki. Az eredetileg 46 tételből álló kérdőívet később 33 kérdésre csökkentették, melyet azóta több országban is validáltak (többek között Brazília, Kína, Spanyolország, Franciaország) (Moreira et al., 2017; Wu, Cai \& Luo, 2017; Cebolla, Barrada, van Strien, Oliver \& Baños, 2014; Bailly, Maitre, Amanda, Hervé \& Alaphilippe, 2012) és hazánkban is sikerrel alkalmaztak (Ercsey, Dernóczy-Polyák \& Keller, 2015; Dernóczy-Polyák \& Keller, 2017; Lipták, Huszár \& Buzás, 2018).

A kérdőív az evési magatartás három sajátos stílusát vizsgálja egy-egy attitüdskálával. Az érzelmi evés skála az érzelmek (például harag, feszültség, idegesség) táplálkozásra gyakorolt hatását vizsgálja ezáltal beazonosítva, hogy az egyén étkezése során mennyire hajlamos érzelmek hatására dönteni. A visszafogott evés skála azt méri, hogy az egyén szándékosan visszafogja-e élelmiszerfogyasztását a testsúly csökkentése vagy a túlsúly megelőzése érdekében. A harmadik, a külső hatásra történö evés skála vizsgálja az egyén éhségérzetétől függetlenül, az élelmiszerekhez kapcsolódó külső ingerek hatására történő fogyasztását (van Strien et al., 1986). Mindezek alapján a DEBQ-skálákkal az egyén evési magatartásának három sajátos stílusát tudjuk beazonosítani, azaz meg tudjuk állapítani, hogy az adott egyénre mennyire jellemző ez a három sajátos evési magatartás. Ez a három evési stílus megfeleltethető a fentiekben bemutatott három sajátos evési magatartás típusnak: visszafogott evés, érzelmi evés és gátlástalan evés.

A DEBQ-kérdőívet már számos nemzetközi kutatás során használták az étkezési magatartás és a BMI (testtömegindex) összefüggéseinek feltárására. Van Strien és szerzőtársai (1985) nők evési magatartását és BMI-indexét vizsgálták kutatásuk során. Pozitív irányú, szignifikáns kapcsolatot mutattak ki a BMI-index és az érzelmek hatására történő evés, valamint a BMI és külső hatásra történő evés között, azonban a BMI-érték és a visszafogott evés között nem találtak kapcsolatot. Anschutz és szerzőtársai (2009) a BMI-index és az energiabevitel összefüggéseit vizsgálták az étkezési magatartás tükrében. A visszafogott evés és az energiabevitel, valamint BMI között negatív, a külső hatásra történő evés esetén pedig pozitív kapcsolatot találtak. Cebolla és társai (2013) kutatása szintén arra a következtetésre jutott, hogy a visszafogott evés és a testsúlymenedzsment között negatív kapcsolat van, míg a másik két érkezési magatartás negatívan hat rá. Ezek alapján feltételezhető, hogy a külső hatásra történő evés és az 
érzelmi evés magasabb kalóriabevitelhez, ezáltal túlsúlyhoz vezet, míg a visszafogott evők sikeresen menedzselik testsúlyukat (Dernóczy-Polyák, Keller \& Ercsey, 2017).

Hazai mintán is sikeresen alkalmazták a DEBQ-kérdőívet, beazonosítva az evési magatartástípusokat, és a külső hatásra történő evés esetén három eltérö faktort is megállapítottak: íz, illat és szociális hatás (Dernóczy-Polyák \& Keller, 2017).

\section{A kutatási modell és a hipotézisek}

Kutatásunk célja volt annak feltárása, hogy a szülők és a gyermekek véleménye mennyiben különbözik a gyermekek táplálkozási szokásainak megítélése során. A kutatást a 62/2018-SZTE számú orvosi etikai engedély alapján valósítottuk meg. A papíralapú kérdőívünket három szegedi általános iskola 3-6. osztályos tanulóinak, illetve az ő szüleiknek juttattuk el. A kérdőíves kutatást kvalitatív kutatás előzte meg a fenti korosztályból néhány diákkal, az elkészült mélyinterjúk alapján arra a következtetésre jutottunk, hogy elég érettek a kérdőív kitöltéséhez. Az iskolák közül egy belvárosi, egy lakótelepi és egy külterületi általános iskola volt. A kérdőív kitöltése anonim módon történt, azonban minden tanulóhoz és szülőhöz tartozott egy azonosítószám, így a szülö-gyerek párosokat össze tudtuk párosítani az elemzés során. A kérdőív kitöltését az iskolák 3-6. osztályos diákok és szüleik közül 100-100 föt szerettünk volna megkérdezni mind a három iskola alsó és felső tagozatából egyaránt. A rekrutálást addig folytattuk, míg el nem értünk a 600 föt. A kitöltés előtt a szülőkkel beleegyező nyilatkozatot töltettünk ki, így csak olyanok kerültek a végső mintába, akik beleegyeztek, hogy ök és gyermekeik is kitöltik a kérdéssort. 600 kérdőívből 433 értékelhető, kitöltött kérdőív érkezett vissza. Az összetartozó szülök és a diákok kérdőíve azonos kódszámon futott, így ezek egymással összepárosíthatók voltak. Emiatt alkalmunk adódott arra, hogy a gyermekek és szüleik véleményét összehasonlíthassuk egymással.

Az elemzés során arra voltunk kíváncsiak, hogy a mintába került szülők, illetve a gyermekek esetén beazonosíthatók-e az eredeti DEBQ-modellfaktorok, azaz az érzelmi evés, a visszafogott evés és a külső hatásra történő evés faktorok leképezhetők-e az eredeti változókból. Emellett azt is vizsgáltuk, hogy a szülök, illetve a gyermekeik között az egyes faktorok esetén van-e szignifikáns különbség, és ha van, akkor milyen módon térnek el a válaszok. Így a hipotéziseink, melyeket teszteltünk, a következők voltak:

- H1.: A DEBQ-modell 3 faktora (érzelmi evés, külső hatásra történő evés, visszafogott evés) beazonosítható a mintán.

- H1a.: A DEBQ-modell három faktora (érzelmi evés, külső hatásra történő evés, visszafogott evés) beazonosítható a gyermek mintán.

- H1b.: A DEBQ-modell három faktora (érzelmi evés, külső hatásra történő evés, visszafogott evés) beazonosítható a szülöi mintán.

• H2.: A gyermekek és a szülők válaszai között különbségek vannak.
- H2a.: Az érzelmi evés faktor esetén különbség van a gyermekek és a szülők válaszai között.

- H2b.: A külső hatásra történő evés faktor esetén különbség van a gyermekek és a szülök válaszai között.

- H2c.: A visszafogott evés faktor esetén különbség van a gyermekek és a szülők válaszai között.

- H3: A gyermekek és szülők válaszai között a gyerekek BMI-kategóriái szerint más-más különbségek vannak.

\section{Módszertan}

Vizsgálódásunk során egy, már korábban validált kérdőív, a DEBQ (Dutch Eating Behavior Questionnaire) (van Strien et al., 1986), valamint a gyerekek vizsgálatára kifejlesztett változatának (DEBQ-C) (van Strien \& Oosterveld, 2008) egy átalunk készített adaptációját használtuk fel. Az eredeti és a gyerekekre adaptált változatból összesen kilenc állítást használtunk fel a gyermek és a szülői kérdőív esetében egyaránt. Az adaptált kérdőív célirányosan gyermekek étkezési szokásainak felmérésére alkalmas mivel rövidebb, azaz az eredeti DEBQ-skáláknál kevesebb kérdéssel méri ugyanazon három táplálkozási stílust. A modell mind a három faktorához (érzelmi evés, viszszafogott evés, külső hatásra történő evés) kapcsolódóan három-három 1-5-ös Likert-skálás állítást választottunk ki. A skálán azt kellett megadniuk a válaszadóknak, hogy mennyire értenek egyet az adott állítással. A gyermekek esetében az állításuk önmagukra, míg a szülők esetében a gyermekükre vonatkozóan voltak feltéve (1. táblázat).

1. táblázat

\section{A gyermek és a szülői kérdőívbe bekerült DEBQ-állítások}

\begin{tabular}{|c|c|}
\hline $\begin{array}{c}\text { Gyermek kérdöívbe került } \\
\text { állítások }\end{array}$ & $\begin{array}{c}\text { Szülői kérdőívbe került } \\
\text { állítások }\end{array}$ \\
\hline $\begin{array}{l}\text { 1. Ha szomorú vagyok, vá- } \\
\text { gyom rá, hogy egyek. }\end{array}$ & $\begin{array}{l}\text { 1. Ha a gyermekem szomorú, } \\
\text { vágyik rá, hogy egyen. }\end{array}$ \\
\hline $\begin{array}{l}\text { 2. Ha magányosnak érzem } \\
\text { magam, vágyom rá, hogy } \\
\text { egyek. }\end{array}$ & $\begin{array}{l}\text { 2. Ha a gyermekem magá- } \\
\text { nyosnak érzi magát, vágyik } \\
\text { rá, hogy egyen. }\end{array}$ \\
\hline $\begin{array}{l}\text { 3. Ha sokat eszek, odafigye- } \\
\text { lek, hogy a következő na- } \\
\text { pokban kevesebbet egyek. }\end{array}$ & $\begin{array}{l}\text { 3. Ha a gyermekem sokat } \\
\text { eszik, odafigyel, hogy a } \\
\text { következő napokban keve- } \\
\text { sebbet egyen. }\end{array}$ \\
\hline $\begin{array}{l}\text { 4. Szándékosan keveset } \\
\text { eszem, hogy ne hízzak. }\end{array}$ & $\begin{array}{l}\text { 4. A gyermekem szándékosan } \\
\text { keveset szokott enni, hogy } \\
\text { ne hízzon el. }\end{array}$ \\
\hline $\begin{array}{l}\text { 5. vGyakran megkívánom az } \\
\text { ételt, ha látom, hogy mások } \\
\text { esznek. }\end{array}$ & $\begin{array}{l}\text { 5. A gyermekem gyakran } \\
\text { megkívánja az ételt, ha lát- } \\
\text { ja, hogy mások is esznek. }\end{array}$ \\
\hline $\begin{array}{l}\text { 6. A finom falatoknak nehe- } \\
\text { zen tudok ellenállni. }\end{array}$ & $\begin{array}{l}\text { 6. A gyermekem a finom } \\
\text { falatoknak nehezen tud } \\
\text { ellenállni. }\end{array}$ \\
\hline $\begin{array}{l}\text { 7. Figyelek arra, hogy zsírsze- } \\
\text { gény ételeket egyek. }\end{array}$ & $\begin{array}{l}\text { 7. A gyermekem figyel arra, } \\
\text { hogy zsírszegény ételeket } \\
\text { egyen. }\end{array}$ \\
\hline
\end{tabular}




\begin{tabular}{|c|c|}
\hline $\begin{array}{c}\text { 8. Ha rossz dolgok történnek, } \\
\text { vágyom rá, hogy egyek. }\end{array}$ & $\begin{array}{c}\text { 8. Ha a gyermekemmel rossz } \\
\text { dolgok történnek, vágyik } \\
\text { rá, hogy egyen. }\end{array}$ \\
\hline $\begin{array}{c}\text { 9. Ha jó illatú vagy finom } \\
\text { ételeket látok, szívesen } \\
\text { megkóstolnám öket. }\end{array}$ & $\begin{array}{c}\text { 9. Ha a gyermekem jó illatú } \\
\text { vagy finom ételeket lát, } \\
\text { szívesen megkóstolja. }\end{array}$ \\
\hline
\end{tabular}

Forrás: DEBQ alapján saját szerkesztés

Az eredeti modell alapján a 9 kérdéses kérdőív esetében az 1., 2. és 8. állítások az érzelmi evés, a 3., 4. és 7. állítások a visszafogott evés, míg az 5., 6. és 9. állítások a külső hatásra történő evés faktorhoz tartoztak.

A kutatás során az IBM SPSS 20 statisztikai szoftvert, illetve a Microsoft Excel programot használtuk fel az adatok elemzésére, és a hipotézisek tesztelésére. Az elemzés során a leíró statisztikai elemzés mellett főkomponenselemzést, skálázást, átlagteszteket, illetve korrelációs együtthatókat is megvizsgáltunk. A tanulmányunkban a főkomponenselemzés eredményeként létrehozott mesterséges változókat az egyszerüsítés és könnyebb megértés kedvéért faktoroknak fogjuk hívni. A létrehozott faktorok belső konzisztenciáját is megvizsgáltuk, a Cronbach Alfa érték minden esetben eléri a 0,6-ot, ezért elfogadhatónak tartjuk (2. táblázat).

2. táblázat

\section{A létrehozott faktorok belső konzisztenciája}

\begin{tabular}{|c|c|c|}
\hline Csoport & Faktor & Cronbach Alfa érték \\
\hline \multirow{4}{*}{ Gyerek } & Érzelmi evés & 0,841 \\
\cline { 2 - 3 } & Külső hatásra evés & 0,693 \\
\cline { 2 - 3 } & Visszafogott evés & 0,670 \\
\hline \multirow{4}{*}{ Szülö } & Érzelmi evés & 0,874 \\
\cline { 2 - 3 } & Külső hatásra evés & 0,670 \\
\cline { 2 - 3 } & Visszafogott evés & 0,649 \\
\hline
\end{tabular}

Forrás: saját szerkesztés

A BMI kiszámítása úgy történik, hogy a kilogrammban mért testsúlyértéket elosztjuk a méterben mért magasság értékének négyzetével. Az így kapott értékek a következő 4 kategóriába sorolhatók: sovány $(<18.5)$, normál súlyú (18.5-24.9), túlsúlyos (25.0-29.9) és elhízott $(30.0=<)$.

\section{Eredmények}

A kérdőívet összesen 433, 10 és 14 év közötti gyermek és hozzájuk tartozó szülő töltötte ki. A gyermekek 49 százaléka fiú, míg 51 százaléka lány volt. Közülük 26,9 százalék harmadik, 35,1 százalék negyedik és 28,1 százalék hatodik osztályos tanuló volt. Az ötödikesek aránya a többi évfolyamhoz képest alacsonyabb volt, ők mindössze a minta 9,9 százalékát tették ki. A megkérdezett gyermekek többsége (86\%) városlakó, míg 12,3 százalékuk lakik faluban, és mindösszesen három fö tanyán. A gyermekek 83,1 százaléka 3-4-5 fős háztartásban él. 8,2 százalékuk kétfős, míg a fenn- maradó 8,7 százalék 5-nél több fős háztartásban él. A szülői mintába kerültek 91,1 százaléka édesanya, 0,6 százalékuk pedig nevelőanya volt, míg az édesapák 8,2 százalékos arányban képviseltették magukat a mintában. Közülük a 82 százalék élettársi kapcsolatban (10\%) vagy házasként együtt él párjával. A fennmaradó 18 százalék közül vannak, akik egyedülállóak $(4,7 \%)$, elváltak (11\%) vagy házasok, de nem élnek együtt párjukkal $(1,2 \%)$, továbbá a mintába került szülők közül egy fő volt, aki özvegy.

\section{A hipotézisvizsgálat eredményei}

Az első hipotézis kapcsán azt teszteltük, hogy a DEBQ-faktorok beazonosíthatók-e az általunk megkérdezett minta esetében mind a gyermekek, mind a szülők esetében. Ennek vizsgálatára főkomponenselemzést végeztünk el. Mind a két esetben azonos beállításokat alkalmaztunk (Varimax rotációs eljárás). A 3. táblázat a gyermek, illetve a felnőtt mintán külön-külön lefuttatott főkomponenselemzés eredményeit foglalja össze. A KMO (Kaiser-Meyer-Olkin) mutató, melyből arra következtetünk, hogy van-e értelme háttérstruktúrát keresni a változók között 0,7-es feletti értéket vesz fel mind a gyermek $(0,701)$, mind a felnőtt $(0,720)$ minta esetében.

3. táblázat

A főkomponenselemzés eredményei a gyermek és felnőtt mintákon

\begin{tabular}{|l|c|c|}
\hline & Gyermek & Felnőtt \\
\hline KMO-mutató értéke & 0,701 & 0,720 \\
\hline Bartlett-teszt sig. értéke & $<0,05$ & $<0,05$ \\
\hline Kumulált varianciahányad (\%) & 67,069 & 66,996 \\
\hline Létrehozott faktorok száma (db) & 3 & 3 \\
\hline
\end{tabular}

Forrás: elemzés saját adatfelvétel alapján

Ebben az esetben érdemes megvizsgálni a Bartlett-tesztet, illetve megnézni, hogy milyen összefüggéseket látunk a mesterséges változók és eredeti változók mátrixában. A Bartlett-teszt szignifikanciaértéke mind a két esetben 0,05 alatti volt, mely azt jelzi, hogy van valamilyen korreláció a változók között. Ez alátámasztja azt, hogy van értelme tovább vizsgálnunk a fökomponenselemzés eredményeit. A Kaiser-kritérium alapján (sajátérték $>1$ ) az elemzés mind a két esetben 3-3 mesterséges változót hozott létre az eredeti 9-9 változóból. Továbbá a kumulált varianciahányad, mely az információtartalom-megörzés mértékét jelenti, mindkét esetben a marketingkutatások küszöbértéke (60\%) felett volt, így már csak azt kellett megvizsgálnunk, hogy az egyes faktorokba tömörített változóink megfelelnek-e az eredeti DEBQ-modellnek. Azt kaptuk eredményül, hogy mindkét minta megfelelt ennek, így az eredeti DEBQ-modell három faktorát be tudtuk azonosítani. A faktorok elnevezését és a faktorokba került eredeti változókat a 4. táblázat foglalja össze. 
4. táblázat

A létrejött faktorok elnevezése és az eredeti változók a két minta esetében

\begin{tabular}{|c|c|c|}
\hline $\begin{array}{c}\text { Faktorok } \\
\text { elnevezése }\end{array}$ & $\begin{array}{c}\begin{array}{c}\text { Gyermek eredeti } \\
\text { változók }\end{array} \\
\end{array}$ & Felnőtt eredeti változók \\
\hline \multirow{3}{*}{$\begin{array}{l}\text { Érzelmi } \\
\text { evés }\end{array}$} & $\begin{array}{l}\text { Ha szomorú vagyok, } \\
\text { vágyom rá, hogy } \\
\text { egyek. }\end{array}$ & $\begin{array}{l}\text { Ha a gyermekem szo- } \\
\text { morú, vágyik rá, hogy } \\
\text { egyen. }\end{array}$ \\
\hline & $\begin{array}{l}\text { Ha magányosnak ér- } \\
\text { zem magam, vágyom } \\
\text { rá, hogy egyek. }\end{array}$ & $\begin{array}{l}\text { Ha a gyermekem ma- } \\
\text { gányosnak érzi magát, } \\
\text { vágyik rá, hogy egyen. }\end{array}$ \\
\hline & $\begin{array}{l}\text { Ha rossz dolgok } \\
\text { történnek, vágyom } \\
\text { rá, hogy egyek. } \\
\end{array}$ & $\begin{array}{l}\text { Ha a gyermekemmel } \\
\text { rossz dolgok történnek, } \\
\text { vágyik rá, hogy egyen. }\end{array}$ \\
\hline \multirow{3}{*}{$\begin{array}{l}\text { Külső ha- } \\
\text { tásra törté- } \\
\text { nő evés }\end{array}$} & $\begin{array}{l}\text { Gyakran megkí- } \\
\text { vánom az ételt, ha } \\
\text { látom, hogy mások } \\
\text { esznek. }\end{array}$ & $\begin{array}{l}\text { A gyermekem gyakran } \\
\text { megkívánja az ételt, } \\
\text { ha látja, hogy mások is } \\
\text { esznek. }\end{array}$ \\
\hline & $\begin{array}{l}\text { A finom falatoknak } \\
\text { nehezen tudok ellen- } \\
\text { állni. }\end{array}$ & $\begin{array}{l}\text { Ha a gyermekem jó illatú } \\
\text { vagy finom ételeket lát, } \\
\text { szívesen megkóstolja. }\end{array}$ \\
\hline & $\begin{array}{l}\text { Ha jó illatú vagy } \\
\text { finom ételeket látok, } \\
\text { szívesen megkóstol- } \\
\text { nám őket. } \\
\end{array}$ & $\begin{array}{l}\text { A gyermekem a finom } \\
\text { falatoknak nehezen tud } \\
\text { ellenállni. }\end{array}$ \\
\hline \multirow{3}{*}{$\begin{array}{l}\text { Visszafo- } \\
\text { gott } \\
\text { evés }\end{array}$} & $\begin{array}{l}\text { Ha sokat eszek, } \\
\text { odafigyelek, hogy a } \\
\text { következő napokban } \\
\text { kevesebbet egyek. }\end{array}$ & $\begin{array}{l}\text { Ha a gyermekem sokat } \\
\text { eszik, odafigyel, hogy } \\
\text { a következö napokban } \\
\text { kevesebbet egyen. }\end{array}$ \\
\hline & $\begin{array}{l}\text { Szándékosan keve- } \\
\text { set eszem, hogy ne } \\
\text { hízzak. }\end{array}$ & $\begin{array}{l}\text { A gyermekem szándéko- } \\
\text { san keveset szokott enni, } \\
\text { hogy ne hízzon el. }\end{array}$ \\
\hline & $\begin{array}{l}\text { Figyelek arra, hogy } \\
\text { zsírszegény ételeket } \\
\text { egyek. }\end{array}$ & $\begin{array}{l}\text { A gyermekem figyel } \\
\text { arra, hogy zsírszegény } \\
\text { ételeket egyen. }\end{array}$ \\
\hline
\end{tabular}

Forrás: elemzés saját adatfelvétel alapján

Mindezek alapján az első hipotézist, miszerint az eredeti DEBQ-modell faktorai beazonosíthatók a mintánkon, a szülői és gyermek minta esetén egyaránt igazolódott, így összességében a H1 esetében elfogadtuk.

A második hipotézisünk kapcsán azt akartuk letesztelni, hogy a létrehozott mesterséges változókat vizsgálva van-e eltérés a gyermek és felnőtt válaszok között faktoronként külön-külön. Ahhoz, hogy ezt vizsgálni tudjuk elöször skálázást hajtottunk végre a minimum-maximum módszer segítségével annak érdekében, hogy az értékeink összemérhetők legyenek. Ezt úgy alakítottuk, hogy az öszszes faktorérték 1 és 5 közötti számértéket vegyen fel, az eredeti változókhoz hasonlóan. Így az eredeti faktorértékek közül a legkisebb 1, míg a legnagyobb 5-ös értéket vett fel, a köztes értékek pedig a két szám közötti (nem feltétlenül egész) számértékké transzformálódtak. Ezután már összehasonlítható változókat kaptunk. A gyermekek és a felnőttek értékeit faktoronként két mintás független átlagteszttel hasonlítottuk össze, továbbá megvizsgáltuk a korrelációs együtthatókat is. A vizsgáltunk eredményeit az 5. táblázat foglalja össze. Az átlagtesztek elvégzése előtt azonban mind a három faktor esetében egyénenként megnéztük az összetartozó szülői és a gyermek faktorok értéke közötti különbségek eloszlását. Ezt azért tartottuk fontosnak, hogy megvizsgáljuk, hogy mekkora a kiugró értékek aránya, ahol a szülői és gyermek válaszok nagyban eltértek, ugyanis ezek nagy aránya torzító hatással lehet az átlagteszt végeredményére. Azt az eredményt kaptuk, hogy mind a három faktorpár esetében a gyermek és a szülöi válaszok több mint 80\%-a maximum 1,5-tel tért el egymástól (1-5-ös skála esetében). A maximum 1,5tel eltérő válaszadók aránya az érzelmi evés faktor esetén $88,5 \%$, a külső hatásra történő evés faktor esetén $82,1 \%$ és a visszafogott evés faktor esetén pedig $84,6 \%$ volt, mely eredményekböl körvonalazóik, hogy minimális volt a kiugró értékek aránya. Mivel mind a három esetben $80 \%$ feletti volt a ,jó viselkedő" válaszok aránya, ezért az átlagteszt alkalmazható, nem torzulnak az eredmények.

5. táblázat

\section{Az átlagteszt eredményei és a korrelációs együtthatók a gyermek és felnőtt faktorok vizsgálata kapcsán}

\begin{tabular}{|l|c|c|c|c|c|}
\hline $\begin{array}{c}\text { Faktor } \\
\text { elnevezése }\end{array}$ & $\begin{array}{c}\text { gyermek } \\
\text { átlag }\end{array}$ & $\begin{array}{c}\text { szülót } \\
\text { átlag }\end{array}$ & $\begin{array}{c}\text { átlagteszt } \\
\text { t érték }\end{array}$ & $\begin{array}{c}\text { átlagteszt } \\
\text { sig. érték }\end{array}$ & $\begin{array}{c}\text { korrelációs } \\
\text { együttható }\end{array}$ \\
\hline $\begin{array}{l}\text { Érzelmi } \\
\text { evés }\end{array}$ & 1.47 & 1.74 & -3.29 & 0.001 & $0.298^{* *}$ \\
\hline $\begin{array}{l}\text { Külső } \\
\text { hatásra } \\
\text { történö } \\
\text { evés }\end{array}$ & 3.32 & 2.87 & 4.55 & $<0.001$ & $0.384^{* *}$ \\
\hline $\begin{array}{l}\text { Vissza- } \\
\text { fogott } \\
\text { evés }\end{array}$ & 2.20 & 2.52 & -3.01 & 0.003 & $0.362^{* *}$ \\
\hline
\end{tabular}

Forrás: elemzés saját adatfelvétel alapján

Az eredmények alapján az mondható el, hogy a szülők és a gyermekek válaszai között minden faktor esetében szignifikáns különbség mutatkozott, így a H2 hipotézist - minden alhipotézisével együtt - elfogadjuk. A korreláció minden esetben szignifikáns, pozitív irányú, gyenge kapcsolatot mutatott ki az összetartozó faktorok között. Az érzelmi evés és a visszafogott evés esetében a szülők összességében jobban egyet értettek az állításokkal, mint gyermekeik, ugyanakkor a gyerekek a külső hatásokat magasabbra pontozták a szüleikhez képest. Ez azt jelenti, hogy a szülök a gyermekeik véleményével összevetve inkább úgy gondolják, hogy gyermekeik odafigyelnek, hogy ne egyenek zsíros ételeket, vagy ne egyenek túl sokat (visszafogott evés), továbbá szerintünk gyermekeik hajlamosabbak arra, hogy rossz kedv esetén ételhez nyúljanak (érzelmi evés), miközben kevésbé gondolják úgy, hogy a gusztusos, jó illatú ételeknek nem tudnak ellenállni gyermekeik (külső hatásokra történő evés). Ugyanakkor azt is érdemes megemlíteni, hogy a gyermekek és a szülők ugyanazoknak a faktoroknak adtak magasabb pontokat. Mind a két csoport egyetértett abban, hogy a külső hatások vannak legnagyobb hatással a gyermekek fogyasztására, a visszafogott evés kevésbé jellemző a gyermekek táplálkozásában, illetve mind a szülők, mind gyermekek 
egyaránt úgy gondolták, hogy a rossz kedv nincsen jelentősebb befolyással táplálkozásukra.

Ezután a H3 hipotézishez kapcsolódóan megvizsgáltuk ugyanazokat a különbségeket mind a négy BMI-szegmensnél, majd átlagoltuk az egyes szegmensek közötti különbségeket. A mintában a BMI-szegmensek alapján 36 gyerek sovány, 254 normál súlyú, 58 túlsúlyos és 23 elhízott. Az eredményeket a 6. táblázat mutatja.

6. táblázat

\section{Az eredmények BMI-szegmensek alapján}

\begin{tabular}{|c|c|c|c|}
\hline & $\begin{array}{l}\text { Érzelmek } \\
\text { hatására } \\
\text { történő evés } \\
\text { (Gyerekek } \\
\text { átlaga mínusz } \\
\text { szülők átlaga) }\end{array}$ & $\begin{array}{l}\text { Külső hatásra } \\
\text { történő evés } \\
\text { (Gyerekek } \\
\text { átlaga mínusz } \\
\text { szülők átlaga) }\end{array}$ & $\begin{array}{l}\text { Visszafogott } \\
\text { evés (Gyerekek } \\
\text { átlaga mínusz } \\
\text { szülők átlaga) }\end{array}$ \\
\hline sovány & $-0,02$ & 0,15 & $-0,21$ \\
\hline $\begin{array}{c}\text { normal } \\
\text { súly }\end{array}$ & $-0,12$ & 0,20 & $-0,05$ \\
\hline túlsúly & $-0,19$ & $-0,05$ & 0,09 \\
\hline elhízott & $\mathbf{- 0 , 5 2}$ & $\mathbf{- 0 , 6 0}$ & $\mathbf{0 , 4 2}$ \\
\hline Össz. & $-0,14$ & 0,11 & $-0,01$ \\
\hline
\end{tabular}

Forrás: saját szerkesztés

Csak az elhízott gyermekek esetében mutatkozott szignifikáns különbség a szülők és a gyermekek értékelése között mindhárom tényező esetében, így a H3 hipotézist csak részben fogadjuk el. Érzelmi evés esetén $-0,52$ volt a különbség, ami azt jelenti, hogy a gyermekek szignifikánsan alacsonyabbra értékelték az érzelmeik (például szomorúság) befolyását arra, hogy evési vágyuk alakuljon ki. Vagyis a szülő szerint a gyermek hajlamosabb az érzelmi evésre, mint amennyit a gyermek magáról gondol. A különbség -0,6 volt a külső hatásra történő evésnél, ami szintén hasonló különbséget jelez, vagyis a szülő úgy érzi, hogy gyermeke inkább elcsábul, mint ahogy azt a gyerek érzi. A visszafogott étkezés esetén $+0,42$ a különbség, ami azt jelzi, hogy a gyerekek úgy érezték, sokkal jobban viszsza tudják fogni étkezésüket, míg szüleik szerint sokkal kevésbé képesek erre.

Bár a különbségek sokkal kisebbek voltak, hasonló különbségeket tapasztalhatunk a túlsúlyos gyermekeknél, míg a normál súly és a sovány esetén az ellenkezőjét találjuk mind a külső, mind pedig a visszafogott étkezés során. Ez utóbbi azt jelenti, hogy a normál súlyú és az sovány gyermekek gyakrabban engednek a külső csábításnak és kevésbé hajlamosak a visszafogott evésre, mint a szüleik gondolják.

Az eredmények alapján elmondható, hogy az evési magatartás vizsgálatakor fontos a vizsgált személyek (jelen esetben gyerekek) testsúlyát is figyelembe venni. Jelen kutatás során különbség figyelhető meg a 4. táblázat (BMI szerinti bontás nélküli) és 5. táblázat (BMI szerinti bontás) eredményei között. A BMI szerinti bontás nélkül az eredmények a normál testsúlyúak eredményeivel vannak összehangban, azonban az elhízottak esetén egészen más figyelhető meg - ez következménye a minta összetételének is, melyben a normál súlyúak többségben voltak

\section{Következtetések}

Kutatásunk során a gyerekek táplálkozási sajátosságait vizsgáltuk a DEBQ-módszer segítségével. Központi célunk egyrészt az volt, hogy a gyerekekre adaptált skála használhatóságát megerősítsük, másfelöl pedig arra kerestük a választ, hogy a szülők másként ítélik-e meg a gyermekük táplálkozási sajátosságait, mint maga a gyermek. A szülők és gyermekeik megítélésben mindhárom vizsgált dimenzió mentén különbség mutatkozott. Általánosságban a szülők a gyerekekhez képest felülértékelték azok visszafogott evési magatartását és alul értékelték a külső hatásra történő evés jelentőségét, míg az érzelmek hatására történő evést mind a gyerekek, mind szüleik kevéssé jellemzőnek vélték. Érdemes azonban megjegyezni, hogy ez az általános eredmény csak a sovány és normál testsúlyú szegmensekre volt igaz, a többi BMI-szegmensben ettől eltérő sajátosságokat tapasztaltunk.

\section{Elméleti következtetések}

A legjelentősebb eltérés az elhízott gyerekek esetén mutatkozott. Ezek a gyerekek a szüleikhez képest alacsonyabbra értékelik a külső hatásra, illetve az érzelmekre történő evési magatartásukat, míg magasabbra értékelik visszafogott evési képességüket. Mindezt úgy foglalhatjuk össze, hogy az elhízott gyerekek magasabb önkontrollt gondolnak magukról, mint szüleik róluk. Ezen eredmények egyik értelmezése az lehet, hogy a szülők reálisabban láthatják az elhízott gyermekek önkontrolljának gyengeségeit, mint maguk a gyerekek, vagyis az elhízott gyermekek maguk sokkal kevésbé ismerik be önuralom-problémáikat, mint a szüleik. Érdekes lehet azonban egy másik értelmezés is, miszerint a szülők már csak akkor látják be gyermekeik önkontrollproblémáit, ha azok már elhíztak. Megfigyelhető, hogy minél nagyobb túlsúllyal rendelkezik a gyerek (azaz minél magasabb BMI-kategóriába került), a szülő annál gyengébbnek érzi gyermeke önkontrollját. Vajon valóban az elhízott gyerekek önkontrollja gyengébb, míg a normál súlyúaké erősebb és ezt a tendenciát a szülők reálisan látják, vagy a szülők egészen egyszerüen a gyermek súlya alapján ítélik meg annak önkontrollját és nem veszik észre, ha gyermekük gyenge önkontrollja miatt potenciálisan nagy eséllyel rendelkezik arra, hogy a későbbiekben elhízottá váljon.

\section{Menedzseri következtetések}

Ebből adódóan eredményeink figyelemfelkeltők, ugyanis úgy tűnik a szülők (tévesen) felülértékelik gyermekeik önmegtartóztató képességét a táplálkozás terén, így egyszersmind feltételezhetjük, hogy kevésbé veszélyesnek érzékelik az elhízás kockázatát gyermekük vonatkozásában, ha az még nem rendelkezik túlsúllyal. Ezek alapján érdemes lenne a gyermekek egészséges táplálkozását célzó kommunikáció során nagyobb hangsúlyt fektetni arra, hogy a szülők figyelmét felhívjuk a gyermekeikkel kapcsolatos önkontrollra vonatkozó álláspontjaik felülvizsgálatára és 
ennek segítségével megakadályozni, hogy a jelenleg még normál testsúlyú gyerekek a jövőben elhízzanak.

Másrészt ha a szülők tisztában vannak gyermekük gyenge önkontrolljával a táplálkozás terén, akkor már normál súly esetén is érdemes lenne közbelépniük, és az egészségtudatos étkezés felé terelni gyermeküket, hogy megelőzzék az elhízást.

\section{A kutatás korlátai és a jövőbeli kutatási irányok}

A BMI egy széles körben használt és elfogadott mérési módszer az elhízás megállapítására, azonban mindenképpen szem előtt kell tartani alkalmazásának limitációit: a BMI fals eredményt mutathat egy izmosabb személy esetén. Ezen esetek kiküszöbölésére a derék-csípő arány mérése lehet megfelelő módszer a BMI mellett, ami a hasi elhízást méri. Kutatásunk korlátja, hogy a mintába túl sok normál testsúlyú gyermek került be, valamint nem vizsgáltunk egyéb befolyásoló tényezőket, mint például az anyagi helyzet vagy a szülők táplálkozási attitűdjei. Egy jövőbeli kutatás során érdemes lenne e tényezőket is vizsgálni, hiszen befolyással lehetnek az eredményekre. Valamint érdemes lehet a vizsgálatot egy speciális, csak magas BMI-kategóriájú gyerekeket és azok szüleit tartalmazó mintán lefolytatni

\section{Felhasznált irodalom}

Adamo, K. B., Papadakis, S., Dojeiji, L., Turnau, M., Simmons, L., Parameswaran, M., Cunningham, J., Pipe, A. L., \& Reid, R. D. (2010). Using path analysis to understand parents' perceptions of their children's weight, physical activity and eating habits in the Champlain region of Ontario. Paediatrics \& Child Health, 15(9), 33-41.

https://doi.org/10.1093/pch/15.9.e33

Anschutz, D. J., Van Strien, T., Van De Ven, M. O. M., \& Engels, R. C. M. E. (2009). Eating styles and energy intake in young women. Appetite, 53(1), 119-122. https://doi.org/10.1016/j.appet.2009.03.016

Baicy, K. (2005). Can food be addictive? Insights on obesity from neuroimaging and substance abuse treatment and research. Nutrition Noteworthy, 7, 1-7. https://escholarship.org/uc/item/8482x2b5

Bailly, N., Maitre, I., Amanda, M., Hervé, C., \& Alaphilippe, D. (2012). The Dutch Eating Behaviour Questionnaire (DEBQ). Assessment of eating behaviour in an aging French population. Appetite, 59(3), 853-858. https://doi.org/10.1016/j.appet.2012.08.029

Black, A. P., D’Onise, K., McDermott, R., Vally, H., \& O'Dea, K. (2017). How effective are family-based and institutional nutrition interventions in improving children's diet and health? A systematic review. BMC Public Health, 17(1), 818. https://oi.org/10.1186/s12889-017-4795-5

Boyland, E. J., \& Whalen, R. (2015). Food advertising to children and its effects on diet: review of recent prevalence and impact data. Pediatric Diabetes, 16(5), 331-337.

https://doi.org/10.1111/pedi.12278
Böröndi-Fülöp N., \& Szakály Z. (2010). Milyen tényezők befolyásolják a fiatalok táplálkozását? In Csépe A. (ed.), „Ujj Marketing Világrend” - MOK XVI. Országos Konferencia Tanulmánykötet (pp. 271-281). Budapest: Budapesti Kommunikációs és Üzleti Főiskola.

Cebolla, A., Barrada, J. R., van Strien, T., Oliver, E., \& Baños, R. (2014). Validation of the Dutch Eating Behavior Questionnaire (DEBQ) in a sample of Spanish women. Appetite, 73, 58-64. https://doi.org/10.1016/j.appet.2013.10.014

Danielsen, K. K., Svendsen, M., Mæhlum, S., \& SundgotBorgen, J. (2013). Changes in Body Composition, Cardiovascular Disease Risk Factors, and Eating Behavior after an Intensive Lifestyle Intervention with High Volume of Physical Activity in Severely Obese Subjects: A Prospective Clinical Controlled Trial. Journal of Obesity, 2013, 1-12. https://doi.org/10.1155/2013/325464

Dernóczy-Polyák A., Keller V. \& Ercsey I. (2017). Evési magatartás vizsgálata a DEBQ skála alapján komplex megközelítésben, avagy az evési stílusok és a háttérváltozók közötti kapcsolat vizsgálata. Marketing \& Menedzsment, 51(3), 50-61. https://journals.lib.pte. hu/index.php/mm/article/view/802/677

Dernóczy-Polyák, A. \& Keller, V. (2017). Klaszterképzés evési magatartás alapján - Fókuszban a generációk. Vezetéstudomány, 48(3), 28-38. https://doi.org/10.14267/VEZTUD.2017.03.03

Dovey, T. M. (2010). Eating Behaviour. London: McGrawHill Education.

Ercsey I., Dernóczy-Polyák A. \& Keller V. (2015). Étkezési stílusok Magyarországon - Az evési magatartás mérési módszerei. In Bíró-Szigeti Sz., Petruska I., Szalkai Zs., Kovács I., \& Magyar M. ( eds.), Marketing hálózaton innen és túl-Az Egyesület a Marketing Oktatásért és Kutatásért XXI. országos konferenciájának tanulmánykötete (pp. 177-187). Budapest: Budapesti Müszaki és Gazdaságtudományi Egyetem.

European Food Information Council (2012). Parental Influence On Children's Eating Habits. Retrieved from https://www.eufic.org/en/archive/article/parentalinfluence-on-childrens-food-preferences-and-energyintake

Finkelstein, E. A., Ruhm, C. J. \& Kosa, K. M. (2005). Economic Causes and Consequences of Obesity. Annual Review of Public Health, 26(1), 239-257. https:// doi.org/10.1146/annurev.publhealth.26.021304.144628

Frayn, M. \& Knäuper, B. (2018). Emotional Eating and Weight in Adults: a Review'. Current Psychology, 37(4), 924-933. https://doi.org/10.1007/s12144-017-9577-9

French, S. A., Epstein, L. H., Jeffery, R. W., Blundell, J. E., \& Wardle, J. (2012). Eating behavior dimensions. Associations with energy intake and body weight. A review. Appetite, 59(2), 541-549. https://doi.org/10.1016/j.appet.2012.07.001

Gál T., Soós M. \& Szakály Z. (2017). Egészségtudatos táplálkozással kapcsolatos fogyasztói insight-ok 
feltárása netnográfiával. Vezetéstudomány, 48(4), 4654.

https://doi.org/10.14267/VEZTUD.2017.04.07

Ganley, R. M. (1989). Emotion and Eating in Obesity: A Review of the Literature. International Journal of Eating Disorders, 8(3), 343-361. https://doi. org/10.1002/1098-108X(198905)8:3<343::AIDEAT2260080310>3.0.CO;2-C

Garner, D. M., \& Garfinkel, P. E. (1979). The Eating Attitudes Test: an index of the symptoms of anorexia nervosa. Psychological Medicine, 9(2), 273-279. https://doi.org/10.1017/s0033291700030762

Gibson, L. Y., Byrne, S. M., Davis, E. A., Blair, E., Jacoby, P. \& Zubrick, S. R. (2007). The role of family and maternal factors in childhood obesity. The Medical Journal of Australia, 186(11), 591-595 https://doi.org/10.5694/j.1326-5377.2007.tb01061.x

Herman, C. P., \& Polivy, J. (1980). Restrained eating. In Stunkard, A. J. (ed.), Obesity (pp. 208-225). Philadelphia: Saunders.

Herman, C. P., \& Mack, D. (1975). Restrained and unrestrained eating. Journal of Personality, 43(4), 647-660. https://doi.org/10.1111/j.1467-6494.1975.tb00727.x

Herman, C. P., \& Polivy, J. (1975). Anxiety, restraint, and eating behavior. Journal of Abnormal Psychology, 84(6), 66-72.

https://doi.org/10.1037/0021-843X.84.6.666

Hofmeister-Tóth, Á. (2016). Fogyasztói értékek, trendek és magatartás: Korreferátum Törőcsik Mária: A fogyasztói magatartás új tendenciái címü tanulmányához. Vezetéstudomány, 47(4), 26-29.

HolczerA.J.\&Kiss V.Á.(2019).Aszülőiegészségtudatosság és az étkezési preferenciáik vizsgálata a gyermekkori elhízás tükrében. Táplálkozásmarketing, 6(2), 27-38. https://doi.org/10.20494/TM/6/2/3

Hong, S. A., Peltzer, K., \& Jalayondeja, C. (2019). Parental misperception of child's weight and related factors within family norms. Eating and weight disorders. EWD, 24(3), 557-564.

https://doi.org/10.1007/s40519-017-0399-4

Huszka P. \& Dernóczy-Polyák A. (2015). Táplálékod legyen egészséged - élelmiszer fogyasztási szokások vizsgálata a fiatalok körében. In Bíró-Szigeti Sz., Petruska I., Szalkai Zs., Kovács I., \& Magyar M. (eds.), Marketing hálózaton innen és túl - Az Egyesület a Marketing Oktatásért és Kutatásért XXI. országos konferenciájának tanulmánykötete (pp. 155-165). Budapest: Budapesti Müszaki és Gazdaságtudományi Egyetem.

Jeffery, A. N., Voss, L. D., Metcalf, B. S., Alba, S., \& Wilkin, T. J. (2005). Parents' awareness of overweight in themselves and their children: cross sectional study within a cohort (EarlyBird 21). BMJ (Clinical Research Ed.), 330(7481), 23-24. https://doi.org/10.1136/bmj.38315.451539.F7

Kaplan, H. I. \& Kaplan, H. S. (1957). The psychosomatic concept of obesity. Journal of Nervous and Mental Disease, 125, 181-201.
Kásler, T. (2017). Application of the Child Eating Behavior Questionnaire in Hungary. In Bányai E., Lányi B., \& Törőcsik M. (eds.), Tükrözödés, társtudományok, trendek, fogyasztás (pp. 521-531). Pécs: Pécsi Tudományegyetem, Közgazdaságtudományi Kar.

Kásler, T. (2019). Eating Behaviors Of PreschoolAged Children - Gender-Linked Differences. Táplálkozásmarketing, 6(2), 13-26. https://doi.org/10.20494/tm/6/2/2

Khatoon, S., Ahmed, A., \& Zubair, M. (2017). Bmi; Dietary Practics of School Going Children and Their Bmi May Predict Future Health Hazards. Professional Medical Journal, 24(9), 1392-1397.

https://doi.org/10.17957/TPMJ/17.3938

Kiss V. \& Szakály Z. (2016). A szülők hatása a középiskolás diákok egészségtudatos táplálkozására. In Fehér A., Kiss V. Á., Soós M., \& Szakály Z. (eds.), Hitelesség és értékorientáció a marketingben (pp. 659-668). Debrecen: Debreceni Egyetem Gazdaságtudományi Kar.

Kourlaba, G., Kondaki, K., Grammatikaki, E., RomaGiannikou, E., \& Manios, Y. (2009). Diet quality of preschool children and maternal perceptions/ misperceptions: the GENESIS study. Public Health, 123(11), 738-742.

https://doi.org/10.1016/j.puhe.2009.10.005

Központi Statisztikai Hivatal (KSH) (2015). Európai lakossági egészségfelmérés, 2014. Statisztikai Tükör, 29(9). https://www.ksh.hu/docs/hun/xftp/stattukor/ elef14.pdf

Központi Statisztikai Hivatal (KSH) (2017). Az egészségügyi kiadások alakulása Magyarországon 2010-2015. Statisztikai Tükör, 2017.03.21. https:// www.ksh.hu/docs/hun/xftp/stattukor/eukiadasok1015. pdf

LaCaille L. (2013). Eating Behavior. In Gellman M.D., \& Turner J.R. (eds.), Encyclopedia of Behavioral Medicine. New York: Springer. https://doi.org/10.1007/978-1-4419-1005-9 1613

Lalonde M. (1974). A new perspective on the health of Canadians. A working document. Ottawa: Government of Canada. http://www.phac-aspc.gc.ca/ph-sp/pdf/ perspect-eng.pdf

Lipták L., Huszár S., \& Buzás N. (2018). Evési magatartás vizsgálata fiatal felnőttek körében - különös tekintettel az eltérő testsúllyal rendelkező fogyasztói csoportokra. In Józsa L., Korcsmáros E., \& Seres Huszárik E. (eds.), A hatékony marketing - EMOK 2018 Nemzetközi Tudományos Konferencia konferenciakötete (pp. 781792). Komárom: Selye János Egyetem.

Lockwood, G. B. (2007). The hype surrounding nutraceutical supplements: Do consumers get what they deserve? Nutrition, 23, 771-772.

https://doi.org/10.1016/j.nut.2007.07.004

Macht, M. (2008). How emotions affect eating: a five-way model. Appetite, 50(1), 1-11.

https://doi.org/10.1016/j.appet.2007.07.002

Malota E., Gyulavári T. \& Bogáromi, E. (2019). „Az vagy, amit megeszel" - a hazai fogyasztók 
egészséges táplálkozással kapcsolatos percepciói és attitüdjei. Vezetéstudomány, 50(1), 80-88.

https://doi.org/10.14267/VEZTUD.2019.01.08

Moreira, G. S. X., Mota, D. C. L., Lorenzato, L., Kakeshita, I. S., Costa, T. M. B., \& Almeida, S. S. (2017). Transcultural Adaptation Procedures for the Dutch Eating Behavior Questionnaire (DEBQ) for Brazil. Avaliçãao Psicológica, 16(4), 426-435. https://doi.org/10.15689/ap.2017.1604.12793

OECD (2017a). Obesity. Update 2017.

OECD (2017b). OECD Health Statistics 2017.

Ogden, C. L., Carroll, M. D., Curtin, L. R., McDowell, M. A., Tabak, C. J., \& Flegal, K. M. (2006). Prevalence of overweight and obesity in the United States, 19992004. JAMA, 295(13), 1549-1555.

https://doi.org/10.1001/jama.295.13.1549

Pfau C., Müller A., Bács Z. \& Bácsné Bába É. (2018). Az egészséges táplálkozás szerepe és jelentősége. Táplálkozásmarketing, 5(1), 49-63. http:// taplalkozasmarketing.com/wp-content/uploads/04 Pfau-et-al_Az-eg\%C3\%A9szs\%C3\%A9ges$\mathrm{t} \% \mathrm{C} 3 \% \mathrm{~A} 1 \mathrm{pl} \% \mathrm{C} 3 \% \mathrm{~A} 11 \mathrm{koz} \% \mathrm{C} 3 \% \mathrm{~A} 1 \mathrm{~s}-\mathrm{szerepe}-$ $\% \mathrm{C} 3 \% \mathrm{~A} 9 \mathrm{~s}$-jelent $\% \mathrm{C} 5 \% 91 \mathrm{~s} \% \mathrm{C} 3 \% \mathrm{~A} 9 \mathrm{ge} . \mathrm{pdf}$

Pocock, M., Trivedi, D., Wills, W., Bunn, F., \& Magnusson, J. (2010). Parental perceptions regarding healthy behaviours for preventing overweight and obesity in young children: a systematic review of qualitative studies. Obesity Reviews : An Official Journal of the International Association for the Study of Obesity, 11(5), 338-353. https://doi.org/10.1111/j.1467-789X.2009.00648.x

Scaglioni, S., Arrizza, C., Vecchi, F., \& Tedeschi, S. (2011): Detreminants of children"s eating behaviour. American Journal of Clinical Nutrition, 94(6), 20062011. https://doi.org/10.3945/ajcn.110.001685

Schachter, S., \& Rodin, J. (1974). Obese humans and rats. New Jersey: Lawrence Erlbaum.

Scott-Andrews, K. Q., Wengrovius, C., \& Robinson, L. E. (2020). Parents accurately perceive problematic eating behaviors but overestimate physical activity levels in preschool children. Eating and Weight Disorders:
Studies on Anorexia, Bulimia and Obesity, Preprints, 2020(May), 1-9.

https://doi.org/10.1007/s40519-020-00926-3

Stunkard, A. J., \& Messick, S. (1985). The three-factor eating questionnaire to measure dietary restraint, disinhibition and hunger. Journal of Psychosomatic Research, 29(1), 71-83.

https://oi.org/10.1016/0022-3999(85)90010-8

Szakály Z. (2019). Fogyasztói trendek a táplálkozásban, különös tekintettel a fiatal korcsoportra. Magyar Tudomány, 180(5), 749-762.

https://doi.org/10.1016/0022-3999(85)90010-8

van Strien, T., \& Oosterveld, P. (2008). The children's DEBQ for assessment of restrained, emotional, and external eating in 7 - to 12-year-old children. International Journal of Eating Disorders, 41(1), 72-81.

https://doi.org/10.1002/eat.20424

van Strien, T., Frijters, J. E. R., Bergers, G. P. A., \& Defares, P. B. (1986). The Dutch Eating Behavior Questionnaire (DEBQ) for Assessment of Restrained Emotional, and External Eating Behavior. International Journal of Eating Disorders, 5(2), 295-315. https:// doi.org/10.1002/1098-108X(198602)5:2<295::AIDEAT2260050209>3.0.CO;2-T

van Strien, T., Frijters, J. E., Roosen, R. G., KnuimanHijl, W. J., \& Defares, P. B. (1985). Eating behavior, personality traits and body mass in women. Addictive Behaviors, 10(4), 333-343. https://doi.org/10.1016/0306-4603(85)90029-2

Varga-Hatos K. \& Karner, C. (2008). A lakosság egészségügyi állapotát befolyásoló tényezők. Egészségügyi Gazdasági Szemle, 46(2), 25-33. https:// weborvos.hu/adat/egsz/2008maj/25-33.pdf

Vázquez, F. L. \& Torres, A. (2012). Behavioral and Psychosocial Factors in Childhood Obesity. In Sevil Ari Yuca (Ed.), Childhood Obesity (pp. 143-166). London: IntechOpen.

Wu, S., Cai, T., \& Luo, X. (2017). Validation of the Dutch Eating Behavior Questionnaire (DEBQ) in a sample of Chinese adolescents. Psychology, Health \& Medicine, 22(3), 282-288.

https://doi.org/10.1080/13548506.2016.1173712 